\title{
DIFFICULTIES IN THE DIAGNOSIS OF INCLUSION BODY MYOSITIS- CASE REPORT
}

Danijela Bazic ${ }^{1}$, Zeljko Todorovic ${ }^{2}$, Gordana Toncev ${ }^{3,4}$, Mirjana Veselinovic ${ }^{1,2}$ and Aleksandra Tomic Lucic ${ }^{1,2}$

${ }^{1}$ Internal Clinic, Department of Rheumathology, Clinical Center "Kragujevac", Serbia

${ }^{2}$ Department of Internal medicine, Faculty of Medical Sciences, University of Kragujevac, Serbia

${ }^{3}$ Clinic of Neurology, Clinical Center "Kragujevac", Serbia

${ }^{4}$ Department of Neurology, Faculty of Medical Sciences, University of Kragujevac, Serbia

\author{
POTEŠKOĆE U POSTAVLJANJU DIJAGNOZE MIOZITISA SA \\ INKLUZIVNIM TELAŠCIMA-PRIKAZ SLUČAJA \\ Danijela Bazić ${ }^{1}$, Zeljko Todorovićn ${ }^{2}$ Gordana Tončev ${ }^{3,4}$, Mirjana Veselinovići ${ }^{1,2}$ i Aleksandra Tomić Lučićc ${ }^{1,2}$ \\ ${ }^{1}$ Interna klinika, Odeljenje za reumatologiju, Klinički centar “Kragujevac”, Srbija \\ ${ }^{2}$ Katedra za internu medicinu, Fakultet medicinskih nauka, Univerzitet u Kragujevcu, Srbija \\ ${ }^{3}$ Klinika za neurologiju, Klinički centar"Kragujevac", Srbija \\ ${ }^{4}$ Katedra za neurologiju, Fakultet medicinskih nauka, Univerzitet u Kragujevcu, Srbija
}

Received / Primljen: 09. 07. 2017.

Accepted / Prihvaćen: 18. 09. 2017.

\section{ABSTRACT}

Inclusion body myositis belongs to the group of idiopathic inflammatory myopathies. Two processes, one autoimmune and the other degenerative, appear to occur in parallel. There are two forms of inclusion body myositis, hereditary and sporadic.

Case report: 47-year-old woman with muscle weakness and atrophy of the distal and proximal muscles, and involvement of quadriceps and deep finger flexors was admitted for neuromuscular evaluation. These changes have been started gradually and insidiously over three years. Electromyography findings were nonspecific and for this reason in the beginning of the disease it was misdiagnosed as demyelization peripheral neuropathy. Muscle biopsy, with the presence of characteristic structures such as rimmed vacuoles and amyloid deposits definitely confirmed the diagnosis of inclusion body myositis. Conclusion: There are several difficulties in the diagnosis of inclusion body myositis as nonspecific EMG findings and overreliance on electrophysiology and lack of the cardinal histological features in muscle biopsy. Although this disease is rare and incurable, making the correct diagnosis is crucial to directing the patient to physical therapy for weakness and occupational therapy to improve a patient's ability in activities of daily living.

Keywords: inclusion body myositis, clinical signs, muscle biopsy

\section{SAŽETAK}

Miozitis sa inkluzivnim telašcima pripada grupi idiopatskih inflamatornih miopatija. U osnovi ovog oboljenja se odvijajau dva paralelana patogenetska procesa, inflamatorni i degenerativni. Postoje dva oblika miozitisa sa inkluzivnim telašcima: sporadični $i$ hereditarni.

Prikaz slučaja: 47 godišnja žena, koja je imala mišićnu slabost, atrofiju distalne $i$ proksimalne muskulature je hospitalizovana zbog evaluacije neuromuskularnog stanja. Opisane mišićne promene su nastale postepeno u periodu od poslednje tri godine. Elektromiografski nalaz je u početku bolesti bio nespecifičan, zbog čega je postavljena pogrešna dijagnoza demijelinizirajuće periferne neuropatije. Kasnije uradena biopsija mišića je pokazala specifične promene za miozitis sa inkluzivnim telašcima, kao što su vakuole $i$ depoziti amiloida. Zaključak: Postoji više poteškoća prilikom postavljanja dijagnoze miozitisa sa inkluzivnim telašcima, kao što su nespecifičan nalaz elektromioneurografije $i$ nedostatak kardinalnih patohistoloških promena prilikom neadekvatnog izvođenja biopsije mišića. Iako je bolest retka $i$ slabo reaguje na konvencionalnu terapiju, postavljanje odgovarajuće dijagnoze je značajno zbog upućivanja pacijenta na fizikalnu i okupacionu terapiju, sa ciljem osposobljavanja pacijenata za aktivnosti svakodnevnog života.

Ključne reči: miozitis sa inkluzivnim telašcima, klinički znaci, biopsija mišića
UDK: 616.74-002-074

Ser J Exp Clin Res 2019; 20 (2): 87-90

DOI: 10.1515/SJECR-2017-0048
Corresponding author: MD PhD Aleksandra Tomic Lucic Department of Internal medicine, Faculty of Medical Sciences,
University of Kragujevac, Serbia
c, Department of Rheumathology, Clinical Center "Kragujevac", Department of Internal medicine, Faculty of Medical Sciences,
University of Kragujevac, Serbia Internal Clinic, Department of Rheumathology, Clinical Center "Kragujevac",
Serbia; Zmaj Jovina 30, 34000 Kragujevac; Serbia; Zmaj Jovina 30, 34000 Kragujevac;
Tel. +381 5050 48, E mail: sanlusa@ptt.rs 


\section{INTRODUCTION}

Inclusion body myositis (IBM) belongs to the group of idiopathic inflammatory myopathies. It is estimated that prevalence ranges from 4.3 per million in the Netherlands to 33 per million in South-East Norway $(1,2)$. There are two forms of IBM, hereditary IBM and sporadic IBM. Hereditary form includes the entire spectrum of autosomal dominant and autosomal recessive muscle disease from which suffers younger population. Sporadic form (sIBM) usually appears as a separate disease, or it is associated with other systemic autoimmune diseases (such as systemic lupus erythematosus, Sjögren's syndrome, systemic sclerosis, etc.) (3,4). In pathogenesis of IBM two processes might occur in parallel: a primary immune process due to T-cell-mediated cytotoxicity, and a non-immune process characterized by vacuolization and intracellular accumulation of amyloid-related molecules, probably due to $\mathrm{MHC}$ class I-induced stress.

Muscle weakness, as the main characteristic of the disease; have been started gradually and insidiously over many months and years. Considering the fact that there are slow development of the disease and nonspecific EMG findings, s-IBM is still difficult to diagnose. It remains frequently misdiagnosed as other neuromuscular conditions by health care professionals. The degenerative processes with amyloid accumulation distinguish sporadic inclusion body myositis from other inflammatory myopathies (5). Muscle biopsy, with the presence of characteristic structures such as rimmed vacuoles and amyloid deposits, using Congo red technique, definitely confirm IBM $(5,6)$. Currently, no effective therapy exists.

\section{CASE REPORT}

A 47-year-old woman was referred to Department of Rheumatology of Internal Clinic for a second-opinion neuromuscular evaluation. Three years before, she noticed leg weakness, particularly in his thighs, and difficulties to stand up from sitting position. After few months, weakness of upper extremity appeared too. Physical examination performed by neurologist, showed lower muscle strength of all extremities with decrease patellar and Achilles reflex bilaterally. Biochemical analysis were in referent range, except total creatine kinase (CK) was mildly elevated at $211 \mathrm{ng} / \mathrm{ml}$ (referent range $<200 \mathrm{ng} / \mathrm{ml}$ ). Electromyography (EMG) was performed and a result was consisted with demyelization peripheral neuropathy more dominant on the lower limbs. Physical therapy partially improved her muscle strength for a short time. Three years after initial symptoms started, patient hospitalized again in the Clinic of Neurology, with signs of severe muscle weakness. This time physical examination showed hypoesthesia of right face side, weakness of neck flexors revealed "drooped neck sign". Weakness and atrophy of the distal and proximal muscles, and involvement of quadriceps, deep finger flexors and ankle dorsiflexors were observed too. Muscle reflex on lower extremities were absent. Repeated EMG showed increased membrane instability and early recruitment with fractionation of the motor unit potentials, showing a brief, small, abundant, polyphasic motor unit potentials (MUPs). Total CK level was elevated at $437 \mathrm{ng} / \mathrm{ml}$ (referent range $<200 \mathrm{ng} /$ $\mathrm{ml})$. Biopsy of the right deltoid muscle was performed and showed myopathic features, variation in muscle fiber size, endomysial fibrosis, chronic inflammatory cells with macrophages, rimmed vacuoles with basophilic stippling and amyloid deposits, using Congo red technique, characteristic of sIBM (Figure 1,2,3). Patient received three cycles of immunoglobulin therapy, $0.5 \mathrm{~g} / \mathrm{kg}$ of IVIG, three times at monthly intervals. After that muscle strength partially improves for a short time. Treatment with glicocorticoids and immunosupresives (azatioprine) as an attempt to suppress inflammation, resulted with normalizing the levels of $\mathrm{CK}$, and was not accompanied by significant improvement in muscle strength. After that observation treatment with glicocorticoids and immunosupresives was interrupted. Patient was directed to the physical therapy for weakness, education to prevent falls and occupational therapy to improve activities of daily living.

\section{DISCUSSION}

There are two parallel processes in IBM pathogenesis: one autoimmune and the other degenerative. In contrast to dystrophies, in IBM the autoinvasive $\mathrm{CD} 8^{+} \mathrm{T}$ cells are cytotoxic and antigen-driven, invading muscle fibers expressing major histocompatibility complex class I antigen and costimulatory molecules. The concurrent degenerative features include vacuolization, filamentous inclusions and intracellular accumulations of amyloid- $\beta$-related molecules $(6,7)$.

sIBM causes weakness and atrophy of the distal and proximal muscles, and involvement of quadriceps and deep finger flexors are clues to early diagnosis $(5,7)$. Patients often present with falls because their muscle weakness, or with difficulty performing certain tasks, such as turning keys, owing to weakness of finger flexors. The tendon reflexes, although preserved early in the disease, can diminish in the late stages as the atrophy of major muscle groups becomes evident (7). Creatine kinase levels can initially be elevated up to 10 -fold, but they remain only slightly elevated as the disease progresses.

EMG findings in IBM have reported a high frequency of spontaneous activity i.e. fibrillations, positive sharp waves and polyphasic motor unit potentials (MUPs) that can occur in a variety of chronic myopathies (4). In some patients, the finding of enlarged MUPs with prominent spontaneous activity can lead to a mistaken diagnosis of a neurogenic disorder, unless a muscle biopsy is performed. EMG findings are nonspecific and for this reason EMG is not included in the diagnostic research criteria for IBM $(6,8)$. However, in clinical practice EMG has an important 


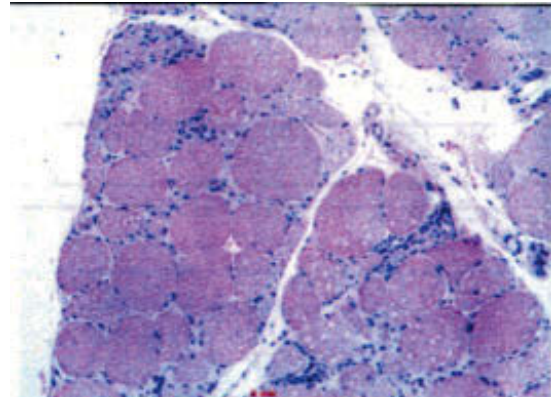

Figure 1. Histopathology finding: Lymphocite inflammatory infiltration of the myscle. There were aso generalized upregulation of sarcolemmal MHC I in zone of cellular infiltration and out of that zone. Expression of dyferlin was normal . (HEx19)

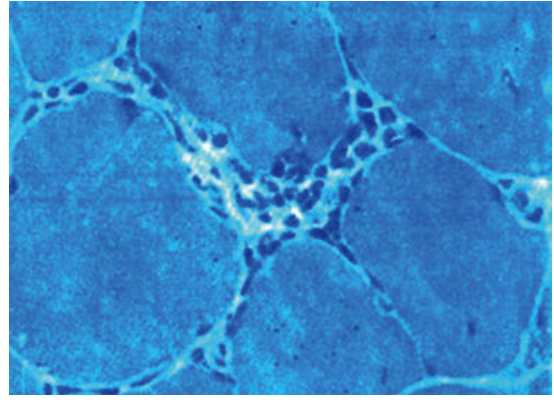

Figure 2. Histopathology finding: Signs of myophagocytosis (mod Gomori trichrome x 40)

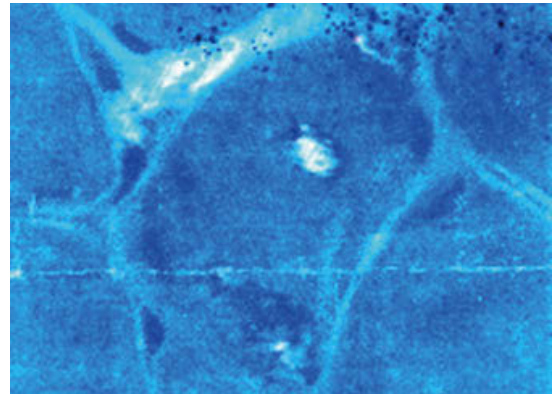

Figure 3. Histopathology finding: Presence of "rimmed vacuoles" in muscle fibers (Mod. Gomori trichrome $\mathrm{x} 40$ ) role in the evaluation of muscle weakness, and may alert the clinician that a muscle biopsy should be performed.

Muscle biopsy is essential for diagnosis. The main histological features are multifocal lymphocytic infiltrates invading non-necrotic muscle fibers, vacuoles in fibers not invaded by lymphocytes (these 'rimmed vacuoles' contain basophilic granular deposits, consisting of membranous whorls, around the edges), and Congo-red-positive amyloid deposits (6). Although individual pathological features are all non specific and can also be seen in other myopathies and neurogenic disorders, their co-occurrence in the same biopsy allows the diagnosis of sIBM (9). Clinicians may be misled by an incomplete biopsy appearance and lack of the cardinal histological features, with patchy inflammatory changes being more florid early and patchy degenerative changes more florid later in the disease course.

The cases described here confirm and highlight the fact that s-IBM is still difficult to diagnose and remains frequently misdiagnosed. Literature data shows that the time to diagnosis averaged 5.83 years. sIBM is often misdiagnosed as polymyositis, granulomatous myositis, myofibrillar myopathies, or motor neuron disease, amyotrophic lateral sclerosis, peripheral neuropathy and other diseases $(10,11)$. It is frequently only suspected retrospectively when a patient does not respond to therapy.

Treatment of IBM is quite a challenge due to IBM resistance on corticosteroids and other immunosuppressive therapies and lack of controlled trials because of the rarity of the disease. $\mathrm{Al}$ though the common immunotherapeutic agents available for inflammatory myopathies, such as corticosteroids, azathioprine, methotrexate, cyclosporine and cyclophosphamide are generally ineffective, some patients have responded to these therapies to a certain degree or for short periods (12). On the other hand, the mechanism by which IVIG affects muscle in inclusion body myositis has not been well-studied. However, it may work via suppression of T-cell activation (including cytotoxic T cells) and migration into muscle tissue and alterations in cytokine production (13). Some patients with IBM respond to intravenous immunoglobulin (IVIG) therapy $(3,13)$. Treatment with IVIG must be administered in the context of its known adverse effects. There is little evidence to advise the clinician on the proper dosing of IVIG and duration of therapy. Considering evidence-based guidelines there are insufficient evidences to support or refute use of IVIG in the treatment of inclusion body myositis $(14,15)$.

However, sIBM remains a disabling disease, with most patients requiring an assistive mobility device within 5 to 10 years of onset. In general, the older the age of onset, the more rapidly progressive is the course.

There are several difficulties in the diagnosis of s-IBM: nonspecific EMG findings and overreliance on electrophysiology, and lack of the cardinal histological features in muscle biopsy. For this reason, it is necessary to notice clinical signs that are crucial for diagnosis, such as long finger flexor and quadriceps weakness.

\section{Declaration of interest}

The authors declare no conflict of interest.

\section{REFERENCES}

1. Badrising UA, Maat-Schieman M, van Duinen SG, Breedveld F, van Doorn P, van Engelen B, et al. Epidemiology of inclusion body myositis in the Netherlands: a nationwide study. Neurology 2000;55(9):1385-7.

2. Dobloug GC, Antal EA, Sveberg L, Garen T, Bitter H, Stjarne J, et al. High prevalence of inclusion body myositis in Norway; a population-based clinical epidemiology study. Eur J Neurol 2015;22(4):672-e41.

3. Dalakas MC. Sporadic inclusion body myositis--diagnosis, pathogenesis and therapeutic strategies. Nat Clin Pract Neurol 2006;2(8):437-47.

4. Needham M, Mastaglia FL. Sporadic inclusion body myositis: A review of recent clinical advances and current approaches to diagnosis and treatment. Clin Neurophysiol 2016 Mar;127(3):1764-73.

5. Brady S, Squier W, Hilton-Jones D. Clinical assessment determines the diagnosis of inclusion body myositis independently of pathological features. J Neurol Neurosurg Psychiatry 2013;84:1240-6. 
6. Hilton-Jones D, Brady S. Diagnostic criteria for inclusion body myositis.. J Intern Med. 2016;280(1):52-62.

7. Catalán M, Selva-O'Callaghan A, Grau J.M. Diagnosis and classification of sporadic inclusion body myositis (sIBM). Autoimmunity Reviews 2014; 13: 363-366.

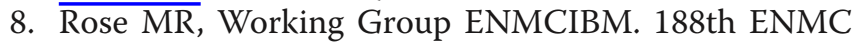
International Workshop: inclusion body myositis. Neuromuscul Disord. 2013;23:1044-55.

9. Brady S, Squier W, Sewry C, Hanna M, Hilton-Jones D, Holton JL. A retrospective cohort study identifying the principal pathological features useful in the diagnosis of inclusion body myositis. BMJ Open. 2014;4:e004552.

10. Larue S, Maisonobe T, Benveniste O, Chapelon-Abric $\mathrm{C}$, Lidove $\mathrm{O}$, Papo $\mathrm{T}$ et al. Distal muscle involvement in granulomatous myositis can mimic inclusion body myositis. J Neurol Neurosurg Psychiatry 2011; 82: 674-7.

11. Schellenberg KL, Johnston WS, Kalra S, Resch L, Johnson ES. Inclusion body myositis masquerading as amyotrophic lateral sclerosis. Can J Neurol Sci. 2010;37(5):687-91.
12. Dalakas MC. Therapeutic approaches in patients with inflammatory myopathies. Semin Neurol 2003; 23: 199-206.

13. Quick A, Tandan R. Mechanisms of action of intravenous immunoglobulin in inflammatory muscle disease. Curr Rheumatol Rep. 2011;13(3):192-8. doi: 10.1007/ s11926-011-0171-0.

14. Patwa HS, Chaudhry V, Katzberg H, Rae-Grant AD, So YT. Evidence-based guideline: intravenous immunoglobulin in the treatment of neuromuscular disorders: report of the Therapeutics and Technology Assessment Subcommittee of the American Academy of Neurology. Neurology. 2012;78(13):1009-15. doi: 10.1212/ WNL.0b013e31824de293.

15. Donofrio PD, Berger A, Brannagan 3rd TH, et al. Consensus statement: the use of intravenous immunoglobulin in the treatment of neuromuscular conditions report of the AANEM Ad Hoc Committee. Muscle Nerve. 2009;40:890-900. 